\title{
Interleukin-10 Inhibits Antigen-induced Cellular Recruitment into the Airways of Sensitized Mice
}

\author{
Claudia Zuany-Amorim, * Solomon Hailé, ${ }^{*}$ Dominique Leduc, ${ }^{*}$ Claude Dumarey, ${ }^{*}$ Michel Huerre, ${ }^{\star}$ B. Boris Vargaftig, ${ }^{*}$ and \\ Marina Pretolani* \\ *Unité de Pharmacologie Cellulaire, Unité Associée Institut Pasteur/Institut National de la Santé et de la Recherche Médicale No. 285; \\ and ${ }^{\ddagger}$ Unité d'Histopathologie, Institut Pasteur, 75015 Paris, France
}

\begin{abstract}
This report examines the effect of recombinant murine (rm) IL-10 on antigen-induced cellular recruitment into the airways of sensitized Balb/c mice. The intranasal instillation of $10 \mu \mathrm{g}$ ovalbumin induced an early $(6-24 \mathrm{~h})$ increase in the number of neutrophils, and a late rise $(24-96 \mathrm{~h})$ in that of eosinophils in the bronchoalveolar lavage (BAL) fluid and bronchial tissue. A single intranasal instillation of $0.01-$ $0.1 \mu \mathrm{g}$ of rmIL-10, administered concurrently with ovalbumin, but not 1 or $3 \mathrm{~h}$ thereafter, dose-dependently inhibited both airway neutrophilia and eosinophilia. This phenomenon was suppressed by treating the sensitized mice with $1 \mathrm{mg} / \mathrm{mouse}$ of a neutralizing anti-IL-10 mAb, which increased significantly ovalbumin-induced neutrophil and eosinophil accumulation in the BAL fluid. These results suggest that antigen stimulation may trigger the in vivo generation of IL-10, which, in turn, participates in the leukocyte infiltration into the airways.

rmIL-10 also reduced TNF- $\alpha$ release in the BAL fluid observed 1 and $3 \mathrm{~h}$ after antigen challenge. Furthermore, the intranasal instillation of an anti-TNF- $\alpha$ antiserum to sensitized mice markedly reduced ovalbumin-induced neutrophil and eosinophil accumulation in the BAL fluid. These findings indicate that leukocyte infiltration into the airways of antigen-challenged mice is regulated by $\mathrm{IL-10}$. Furthermore, inhibition of TNF- $\alpha$ production by rmIL-10 suggests that allergic airway inflammation and TNF- $\alpha$ formation are parallel events in this model. (J. Clin. Invest. 1995. 95:26442651.) Key words: bronchial inflammation - eosinophils • neutrophils • tumor necrosis factor
\end{abstract}

\section{Introduction}

Airway infiltration by inflammatory cells, particularly of eosinophils, is one of the characteristic features of asthma (1). Several mechanisms responsible for the attraction and localization of inflammatory cells at site of allergic reactions have been proposed. Among them, attention is presently focused on the hy-

Address correspondence to Dr. Marina Pretolani, Unité de Pharmacologie Cellulaire, Unité Associée Institut Pasteur/Institut National de la Santé et de la Recherche Médicale No. 285, 25, rue du Dr. Roux, 75015 Paris, France. Phone: 33-1-40-61-32-02; FAX: 33-1-45-68-87-03.

Received for publication 23 September 1994 and in revised form 23 January 1995.

J. Clin. Invest.

(c) The American Society for Clinical Investigation, Inc. $0021-9738 / 95 / 06 / 2644 / 08 \cdot \$ 2.00$

Volume 95, June 1995, 2644-2651 pothesized switching of $\mathrm{CD} 4^{+} \mathrm{T}$ lymphocytes for the preferential production of Th2-derived cytokines (2-4). These cytokines include IL-5, which promotes the growth, differentiation, survival, and activation of eosinophils (5-7) and IL-4, which induces IgE production by B cells (8). In murine models of allergic inflammation, infiltration of the airways by eosinophils is regulated by IL- 5 and IL-4, since sensitized mice treated with anti-IL-5 (9) or anti-IL-4 (10) antibodies display reduced eosinophils in their bronchoalveolar lavage (BAL) ${ }^{1}$ fluid and bronchial tissue after antigen challenge.

IL-10 was initially characterized as a product of $\mathrm{CD}^{+}{ }^{+} \mathrm{T}$ lymphocytes of the Th2 subtype (11) and shown to inhibit IFN$\gamma$ production by Th1 clones (12). Several properties of IL-10 on various cell types have been described since then, including growth stimulation of thymocytes, mast cells, and B cells, and inhibition of cytokine production by activated monocytes, macrophages (reviewed in reference 13) and, more recently, by neutrophils $(14,15)$ and eosinophils (16). Only a few studies, however, have focused on the in vivo modulatory properties of IL-10 during inflammatory reactions. In particular, Howard et al. (17) and Gerard et al. (18), recently demonstrated that the administration of IL-10 protects mice from LPS-induced death and the accompanying rise in the levels of circulating TNF- $\alpha$, suggesting an involvement of IL-10 in inflammatory diseases such as bacterial sepsis. At this time, however, the ability of IL-10 to influence in vivo allergic airway inflammation has not been investigated.

In this report, we show that the intranasal administration of ovalbumin to sensitized Balb/c mice induces an early generation of TNF- $\alpha$ in the BAL fluid, which is followed by airway neutrophilia and eosinophilia. Treatment of the sensitized mice with recombinant murine $(\mathrm{rm}) \mathrm{IL}-10$, concurrently administered with ovalbumin, abrogates antigen-induced airway inflammation and TNF- $\alpha$ generation in the BAL fluid, suggesting that IL10 plays an important role in regulating allergic inflammatory processes in the lung.

\section{Methods}

Mice and immunization. Male Balb/c mice aged $8 \mathrm{wk}$, weighing $\sim 25$ $30 \mathrm{~g}$ (Iffa-Credo, Saint-Germain sur l'Arbresle, France) were sensitized by two subcutaneous injections, 1 wk apart, of $0.4 \mathrm{ml} 0.9 \% \mathrm{wt} / \mathrm{vol}$ $\mathrm{NaCl}$ (saline) containing $100 \mu \mathrm{g}$ ovalbumin (ICN Biomedicals, Inc., Costa Mesa, CA), adsorbed in $1.6 \mathrm{mg}$ aluminium hydroxide (Merck, Darmstadt, Germany). 7-10 d after the second immunization, sensitized mice were challenged by an intranasal administration of ovalbumin, as described below. This immunization procedure favors the production of

1. Abbreviations used in this paper: $\mathrm{BAL}$, bronchoalveolar lavage; $\mathrm{EPO}$, eosinophil peroxidase; PBS-T, PBS-Tween 20; PBS-T-BSA, PBSTween 20-BSA; rm, recombinant murine. 


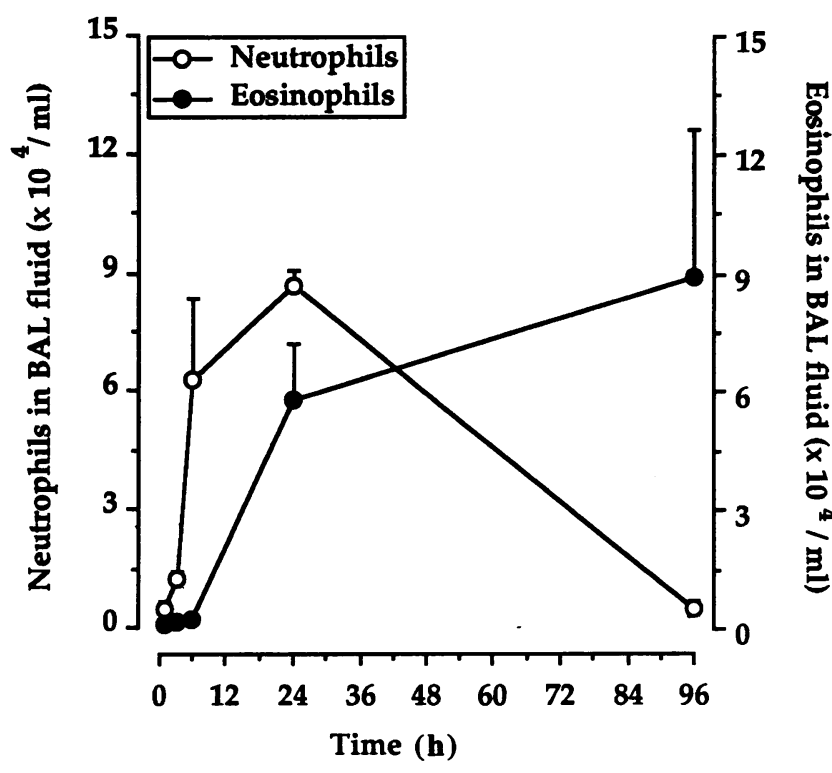

Figure 1. Time course of antigen-induced cellular accumulation in the BAL fluid from sensitized Balb/c mice. Mice were challenged by an intranasal instillation of $10 \mu \mathrm{g}$ ovalbumin, killed at different time intervals after the challenge, and neutrophils $(O)$ and eosinophils $(\bullet)$ were counted in the BAL fluid after cytocentrifugation and staining with DiffQuik stain. Results are expressed as means \pm SEM of six to nine experiments at each time point.

IgE-like homocytotropic antibodies, as measured by passive cutaneous anaphylaxis (19).

Bronchoalveolar cell counts and differentiation. Cellular accumulation into the BAL fluid from sensitized mice was induced by the intranasal instillation of $50 \mu \mathrm{l}$ of a solution containing $200 \mu \mathrm{g} / \mathrm{ml}$ ovalbumin diluted in sterile saline ( $10 \mu \mathrm{g}$ ovalbumin, as final dose administered). Control animals received the same volume of sterile saline. At various time intervals after challenge, mice were anesthetized by an intraperitoneal injection of $4 \mathrm{mg} / \mathrm{kg}$ sodium pentobarbital (Clin-Midy, Montpellier, France) and bronchoalveolar cells were collected in four successive lavages using 1-ml aliquots of sterile saline at room temperature, injected, and recovered through a polyethylene tracheal cannula. Total cells were counted using a Coulter Counter ZM (Coultronics, Margency, France). Differential cell counts were performed after cytocentrifugation (Hettich Universal, Tuttlingen, Germany) and staining with Diff-
Quik stain (Baxter Dade AG, Duedingen, Switzerland). Results are expressed as the number of each population per milliliter BAL fluid. Aliquots of $0.5 \mathrm{ml}$ of the remaining lavage fluid were centrifuged at $200 \mathrm{~g}$ for $15 \mathrm{~min}$, at $4^{\circ} \mathrm{C}$ and the supernatant was collected and stored at $-80^{\circ} \mathrm{C}$ until the determination of TNF- $\alpha$, as described below.

Histology. After the BAL collection was performed as described above, mice were exsanguinated via the abdominal aorta and the lungs were inflated by injecting into the trachea $1 \mathrm{ml}$ solution of optimum cutter temperature compound (BDH, Poole, United Kingdom) in distilled water ( $\mathrm{vol} / \mathrm{vol})$. The lobes were dissected and mounted over cork disks, covered by optimum cutter temperature compound and snap frozen in isopentane (Prolabo, Paris, France) cooled by liquid nitrogen. The frozen blocks were kept at $-80^{\circ} \mathrm{C}$ before use. Sections alongside the main intrapulmonary bronchus were cut in a cryostat kept at $-21^{\circ} \mathrm{C}$ and collected on glass slides previously coated with $\gamma$-methacryloxypropyltrimethoxysilane (Sigma Chemical Co., St. Louis, MO), fixed in acetone (Merck) for $10 \mathrm{~min}$, wrapped in a plastic film, and kept at $-20^{\circ} \mathrm{C}$ before use. Cyanide-resistant eosinophil peroxidase (EPO) activity, using potassium cyanide, diaminobenzidine, and hydrogen peroxide (Merck), was used to stain the eosinophils (20).

Sections were coded and read in a blind fashion. Positive cells were enumerated in the bronchial submucosa by means of a micrometer. The results of each stained slide were expressed as the number of EPOpositive cells per millimeter of basal lamina.

Effect of murine rmIL-10. To determine whether IL-10 regulates antigen-induced cellular infiltration into the airways, sensitized mice received a single intranasal instillation of $0.01,0.03,0.1$, or $0.5 \mu \mathrm{g}$ rmIL-10 (Immugenex, Los Angeles, CA), diluted in $25 \mu \mathrm{l}$ sterile saline, and mixed with an equal volume of a solution containing $400 \mu \mathrm{g} / \mathrm{ml}$ ovalbumin ( $10 \mu \mathrm{g}$ as final dose instilled). Cellular infiltration and TNF$\alpha$ release in the BAL fluid were evaluated $1,3,6,24$, or $96 \mathrm{~h}$ after antigen challenge.

In preliminary experiments, the subcutaneous administration of 0.1 $0.5 \mu \mathrm{g}$ rmIL-10, $1 \mathrm{~h}$ before antigen challenge, failed to modify ovalbumin-induced neutrophil and eosinophil accumulation in the BAL fluid (data not shown).

Effect of anti-murine IL-10 $\mathrm{mAb}$ and of anti-TNF- $\alpha$ antiserum. Sensitized mice were injected intravenously with $1 \mathrm{mg}$ of a rat IgG1 anti-mouse IL-10 mAb, termed 2A5, or with its matched isotype control mAb, GL113 (17), (kindly provided by Dr. R. L. Coffman, DNAX Research Institute, Palo Alto, CA; and by Dr. H. F. J. Savelkoul, Erasmus University, Rotterdam, The Netherlands), $1 \mathrm{~h}$ before the intranasal administration of ovalbumin alone or with $0.1 \mu \mathrm{g} \mathrm{rmIL}-10$.

In separate experiments, $50 \mu \mathrm{l}$ of a sheep anti-mouse TNF- $\alpha$ antiserum (21), or its control preimmune serum (a gift from Drs. S. Poole and A. Meager, National Institute for Biological Standards and Control, Potters Bar, United Kingdom) were administered via the intranasal route, concomitantly with ovalbumin.
A

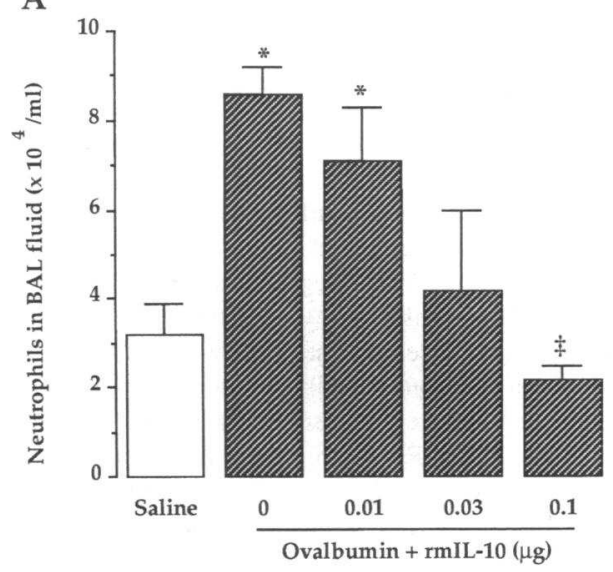

B

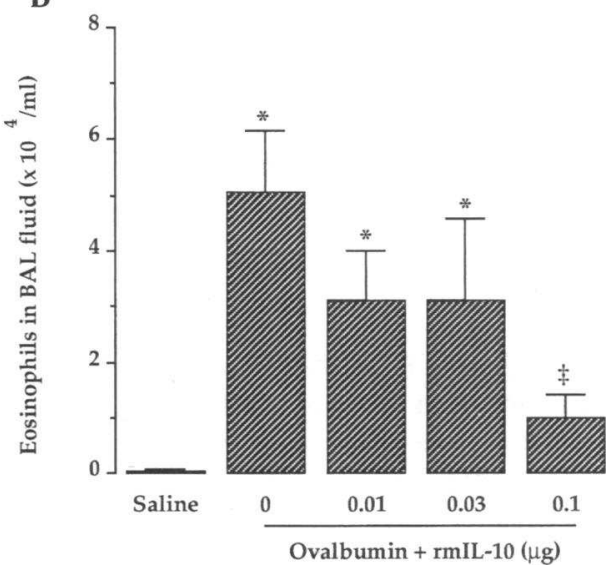

Figure 2. Effect of rmIL-10 on antigen-induced cellular accumulation in the BAL fluid from sensitized $\mathrm{Balb} / \mathrm{c}$ mice. Mice were challenged by intranasal route either with saline, or with $10 \mu \mathrm{g}$ ovalbumin alone or concurrently administered with $0.01,0.03$, or $0.1 \mu \mathrm{g}$ rmIL-10. Neutrophil $(A)$ and eosinophil $(B)$ infiltration in the BAL fluid was evaluated 6 or $24 \mathrm{~h}$ after antigen challenge, respectively. Results are expressed as means \pm SEM of six to nine experiments for each group. ${ }^{*} P$ $<0.05$ and ${ }^{\ddagger} P<0.05$, as compared to saline- or ovalbuminchallenged untreated mice, respectively. 
A

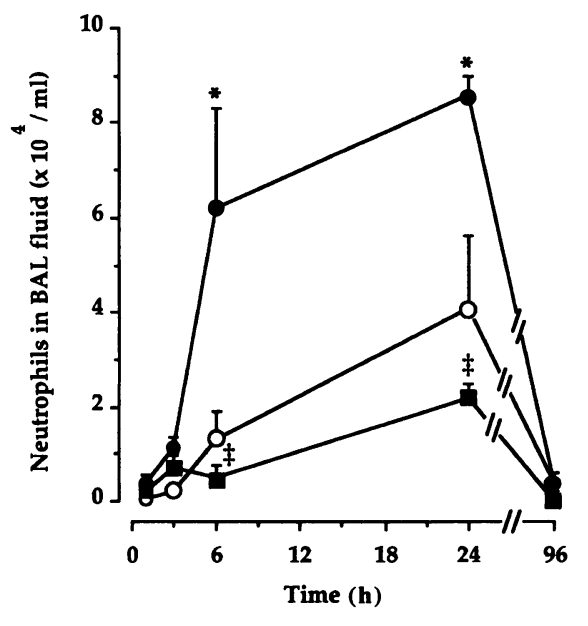

B

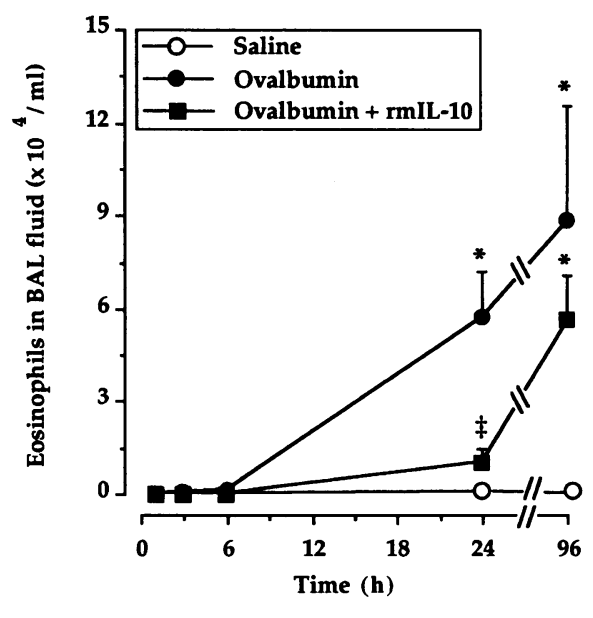

Figure 3. Kinetics of inhibition by rmIL-10 of antigen-induced neutrophil $(A)$ and eosinophil $(B)$ accumulation in the BAL fluid from sensitized Balb/c mice. Mice were challenged by intranasal route with saline $(O)$, or with 10 $\mu \mathrm{g}$ ovalbumin alone $(\bullet)$, or concurrently administered with $0.1 \mu \mathrm{g}$ rmIL-10 (घ), and they were killed at different time intervals after the challenge. Results are expressed as means \pm SEM of six to nine experiments for each group. $* P$ $<0.05$ and ${ }^{\ddagger} P<0.05$, as compared to saline- or ovalbuminchallenged untreated mice, respectively.
In both series of experiments, cell counts in the BAL fluid were evaluated 6 and $24 \mathrm{~h}$ after antigen challenge.

TNF- $\alpha$ determination. The levels of TNF- $\alpha$ in the supernatant of BAL fluid from sensitized saline- or ovalbumin-challenged untreated or rmIL-10 $(0.1$ or $0.5 \mu \mathrm{g})$-treated mice were determined by a specific double sandwich ELISA. Briefly, ELISA plates (96-well-Immuno Plate MaxiSorp; Nunc, Roskilde, Denmark) were coated with $100 \mu \mathrm{l}$ of a rat anti-mTNF- $\alpha$ mAb (Clinisciences-Endogen, Montrouge, France), at 5 $\mu \mathrm{g} / \mathrm{ml}$ in PBS, $\mathrm{pH} 7.4$, and incubated overnight at room temperature in the dark. The day after, the wells were washed three times with PBS containing $0.1 \%$ Tween 20 (PBS-T) and $200 \mu$ l of PBS-T containing $0.1 \%$ BSA (PBS-T-BSA) were added to each well.

After $1 \mathrm{~h}$ at $37^{\circ} \mathrm{C}$ followed by three washes with PBS-T-BSA, 100 $\mu l$ of the samples or rmTNF- $\alpha$ standards (kindly provided by Dr. G. R. Adolf, Boehringer Institut für Arzneimmittel-Forschung, Vienna, Austria), at concentrations ranging between 50 and 3,200 pg/ml in PBST-BSA were added to each well and incubated at $37^{\circ} \mathrm{C}$ for $1 \mathrm{~h}$. The wells were washed three times with PBS-T and incubated for $1 \mathrm{~h}$ at $37^{\circ} \mathrm{C}$ with $100 \mu \mathrm{l}$ of a solution of polyclonal rabbit anti-mTNF- $\alpha$ (Clinisciences-Endogen), at $5 \mu \mathrm{g} / \mathrm{ml}$ in PBS-T-BSA. After the wells were washed three times with PBS-T, $100 \mu$ l of horseradish peroxidaseconjugated goat anti-rabbit IgG $\mathrm{F}\left(\mathrm{ab}^{\prime}\right)_{2}$ (Biosis, Compiègne, France), at a dilution of $1 / 2,000$ in PBS-T-BSA, was added for $1 \mathrm{~h}$ at $37^{\circ} \mathrm{C}$. Then, $100 \mu \mathrm{l}$ of freshly prepared substrate solution (orthophenylenediamine; Sigma Chemical Co.), at $2 \mathrm{mg} / \mathrm{ml}$ and $3 \% \mathrm{H}_{2} \mathrm{O}_{2}$ (Merck) was added to each well. After $7 \mathrm{~min}$ incubation in the dark, at room temperature, the reaction was stopped by the addition to each well of $50 \mu \mathrm{l}$ of a $0.5 \%$ solution of $\mathrm{Na}_{2} \mathrm{SO}_{3}$ (Merck). Absorbance was read at $490 \mathrm{~nm}$ with an automatic microplate-reader (Dinatech MR 5000; Dinatech Laboratories, Saint-Cloud, France). The lower limit of sensitivity of the assay was $50 \mathrm{pg}$ TNF- $\alpha / \mathrm{ml}$ sample.

Data analysis. Results are expressed as means \pm SEM of the indicated number of experiments. One-way ANOVA was used to determine significance among the groups. If a significant variance was found, an unpaired Student's $t$ test was used to assess comparability between means. A value of $P \leq 0.05$ was considered significant.

\section{Results}

Kinetics of antigen-induced cellular infiltration in the BAL fluid from sensitized mice. The intranasal instillation of $10 \mu \mathrm{g}$ ovalbumin to sensitized Balb/c mice induced a rise in the number of neutrophils in the BAL fluid, which reached a maximum between 6 and $24 \mathrm{~h}$ and resolved thereafter (Fig. 1). Intense eosinophil accumulation was observed at $24 \mathrm{~h}$ and progressively increased until $96 \mathrm{~h}$ (Fig. 1). The number of eosinophils returned to background levels $14 \mathrm{~d}$ after antigen challenge (data not shown).

No changes in alveolar macrophage counts were observed, at, any time point after antigen administration (data not shown).

Nonimmunized mice challenged with ovalbumin show a number of neutrophils in the BAL fluid similar to that found in sensitized saline-challenged animals. No eosinophils were enumerated at $24 \mathrm{~h}$ (data not shown).

The times of 6 and $24 \mathrm{~h}$ were selected to study the effect

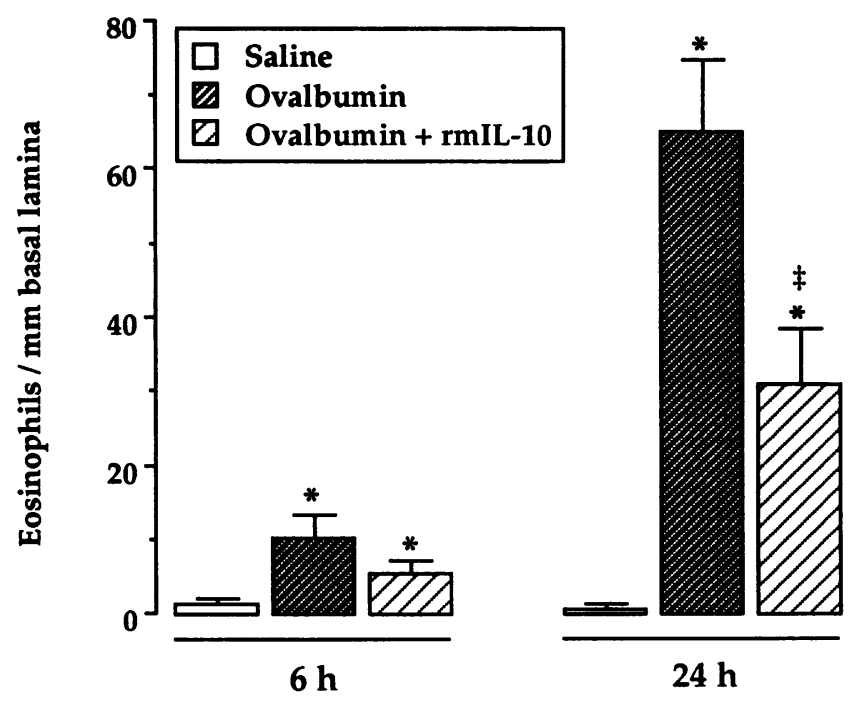

Figure 4. Effect of rmIL-10 on eosinophil infiltration in the bronchial tissue of antigen-challenged mice. Sensitized Balb/c mice were challenged with intranasal saline ( $\square$ ), or with $10 \mu \mathrm{g}$ ovalbumin, administered either alone $(\square)$, or with $0.1 \mu \mathrm{g} \mathrm{rmIL-10}(\Xi)$, and they were killed 6 (left) or $24 \mathrm{~h}$ (right) after the challenge. The number of infiltrating eosinophils was evaluated in the bronchial submucosa by cyanide-resistant EPO activity technique. Data are expressed as the number of EPOpositive cells $/ \mathrm{mm}$ of basal lamina. Results represent the means \pm SEM of seven to nine experiments for each group. ${ }^{*} P<0.05$ and ${ }^{\ddagger} P<$ 0.05 , as compared to saline- or ovalbumin-challenged untreated mice, respectively. 

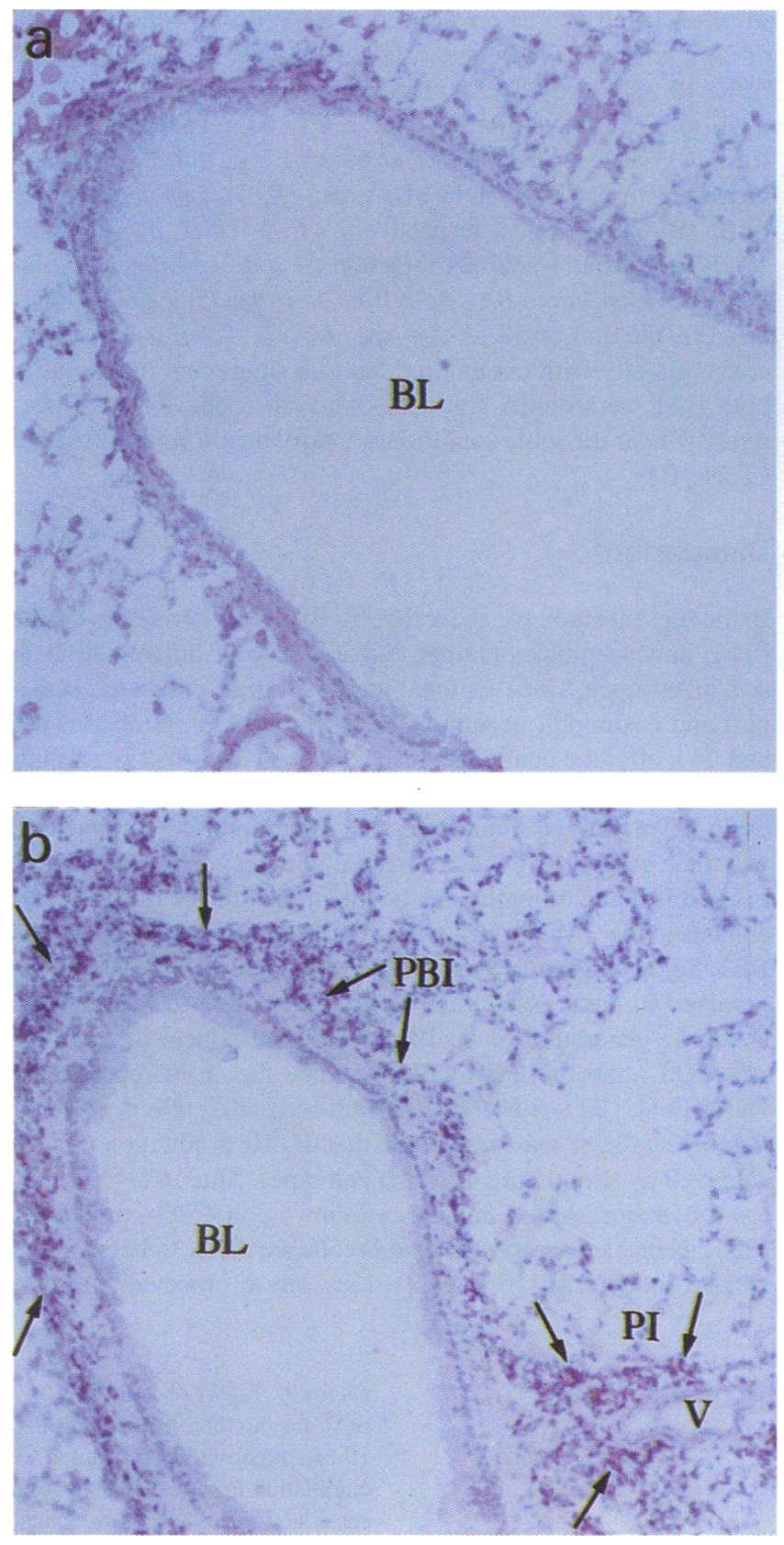

of rmIL-10 and of anti-IL-10 mAb of antigen-induced neutrophilia and eosinophilia in the BAL fluid, respectively.

Effect of rmIL-10 on antigen-induced cellular infiltration in the BAL fluid and bronchial tissue from sensitized mice. A single intranasal administration of $0.01,0.03$, or $0.1 \mu \mathrm{g} \mathrm{rmIL-10} \mathrm{to}$ sensitized mice, instilled concurrently with ovalbumin, inhibited dose-dependently neutrophil and eosinophil infiltration in the BAL fluid observed 6 and $24 \mathrm{~h}$ after the challenge, respectively (Fig. 2). At the highest dose ( $0.1 \mu \mathrm{g} /$ mouse), rmIL-10 suppressed allergic neutrophilia and decreased by $\sim 75 \%$ eosinophilia $(P<0.001)$.

A kinetics study showed significant protection of both BAL neutrophilia and eosinophilia until $24 \mathrm{~h}$ after ovalbumin and rmIL-10 $(0.1 \mu \mathrm{g})$ administration (Fig. 3). In particular, neutrophil numbers in ovalbumin-challenged rmIL-10-treated mice were below those found in control saline-stimulated animals

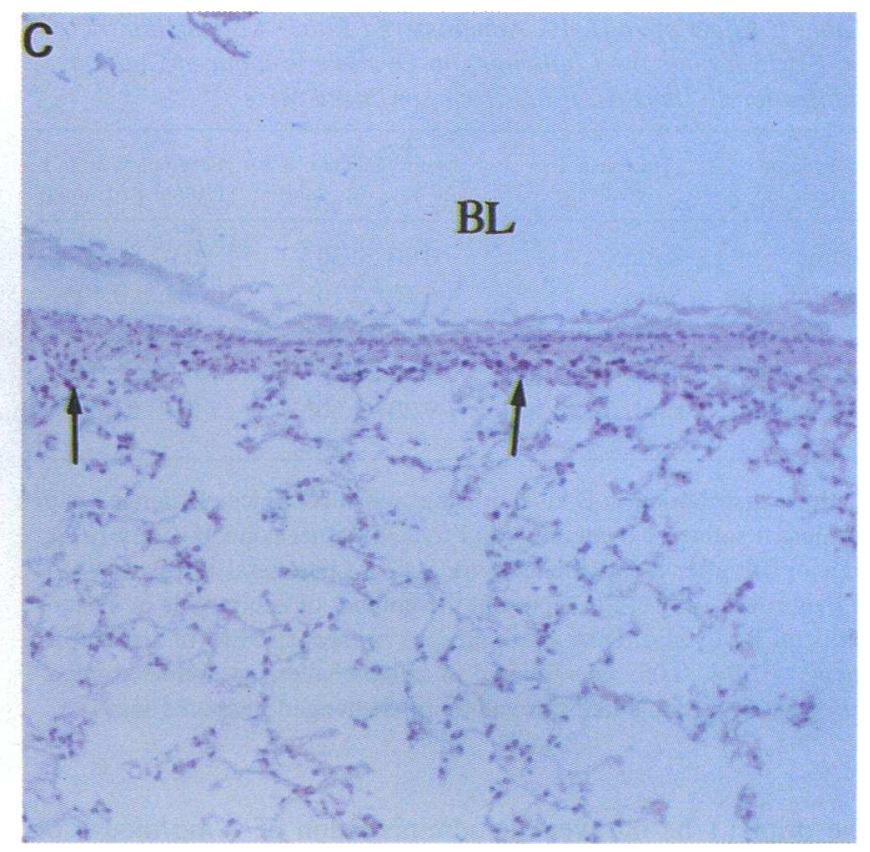

Figure 5. Cyanide-resistant eosinophil peroxidase activity in the bronchial wall of sensitized saline- or antigen-challenged mice. (a) Lung section from an immunized saline-challenged mouse, showing no inflammatory infiltrate around the bronchial lumen; $(b)$ ovalbumin-challenged mouse used $24 \mathrm{~h}$ after the challenge, showing massive eosinophil infiltration concentrated around a vessel and the bronchial submucosa (arrows); (c) ovalbumin-challenged rmIL-10 $(0.1 \mu \mathrm{g} /$ mouse $)$-treated mouse with scant eosinophils in the bronchial submucosa (arrows). BL, bronchial lumen; $V$, vessel, $P I$, perivascular infiltrate; $P B I$, peribronchial infiltrate. $\times 200$.

(Fig. 3). At $96 \mathrm{~h}$, however, only a slight and nonsignificant decrease in the numbers of eosinophils was noted in antigenchallenged rmIL-10 $(0.1 \mu \mathrm{g})$-treated mice, as opposed to controls (Fig. 3). Antigen challenge also induced a time-dependent rise in the number of eosinophils in the bronchial tissue, mainly at $24 \mathrm{~h}$ (Figs. 4 and 5). Treatment with $0.1 \mu \mathrm{g}$ rmIL-10, markedly decreased ovalbumin-induced eosinophil infiltration in the bronchial tissue and significant inhibition was observed at 24 $h$ (Figs. 4 and 5 ).

The intranasal administration of $0.1 \mu \mathrm{g} \mathrm{rmIL}-10,1$ or $3 \mathrm{~h}$ after antigen challenge, failed to protect sensitized mice from antigen-induced cellular accumulation in the BAL fluid ( Table I).

Effect of anti-IL-10 mAb on antigen-induced cellular infiltration in the BAL fluid from sensitized mice. IL-10-mediated inhibition of allergic airway inflammation was suppressed by 
Table I. Effect of rmIL-10, Administered Either Concomitantly, or 1 or $3 \mathrm{~h}$ after the Challenge, on Ovalbumin-induced Cellular Infiltration in the BAL Fluid from Sensitized Mice

\begin{tabular}{llcc}
\hline $\begin{array}{c}\text { Type of } \\
\text { challenge }\end{array}$ & $\begin{array}{c}\text { Treatment after } \\
\text { challenge }\end{array}$ & $\begin{array}{c}\text { Neutrophils at } 6 \mathrm{~h} \\
\left(10^{4} / \mathrm{ml} \text { BAL fluid }\right)\end{array}$ & $\begin{array}{c}\text { Eosinophils at } 24 \mathrm{~h} \\
\left(10^{4} / \mathrm{ml} \mathrm{BAL} \mathrm{fluid}\right)\end{array}$ \\
\hline Saline & Saline & $0.90 \pm 0.30$ & $0.02 \pm 0.02$ \\
Ovalbumin & Saline & $6.20 \pm 2.10^{*}$ & $3.20 \pm 0.40^{*}$ \\
Ovalbumin & rmIL-10 $(0 \mathrm{~h})$ & $0.50 \pm 0.25^{\ddagger}$ & $1.04 \pm 0.40^{\ddagger}$ \\
Ovalbumin & rmIL-10 $(1 \mathrm{~h})$ & $4.90 \pm 0.20^{*}$ & $3.60 \pm 1.00^{*}$ \\
Ovalbumin & rmIL-10 $(3 \mathrm{~h})$ & $9.20 \pm 2.60^{*}$ & $2.70 \pm 1.20^{*}$ \\
\hline
\end{tabular}

Cellular distribution in BAL fluid from sensitized mice challenged with intranasal saline or ovalbumin and treated, either concomitantly $(O h)$, or 1 or $3 \mathrm{~h}$ after the challenge with a single intranasal instillation of $0.1 \mu \mathrm{g} \mathrm{rmIL}-10$. Results represent the number of neutrophils or eosinophils/ml BAL fluid. Data are expressed as means \pm SEM of six experiments. ${ }^{*} P<0.05$, as compared to saline-challenged untreated mice. ${ }^{\ddagger} P<0.05$, as compared to ovalbumin-challenged untreated mice.

the prior $(1 \mathrm{~h})$ intravenous administration of $1 \mathrm{mg} /$ mouse of the rat anti-mouse IL-10 mAb, 2A5, but not of its matched isotype, GL113 (Fig. 6), indicating that the effect of rmIL-10 was due exclusively to its biological activity.

In separate experiments, the in vivo neutralization of IL-10 led to a significant $(P<0.05, n=4-6)$ increase in the number of neutrophils and eosinophils in the BAL fluid 6 and $24 \mathrm{~h}$ after the challenge, respectively, (data not shown). This effect was not an artifact, since the intravenous injection of $1 \mathrm{mg} \mathrm{GL113}$ or $2 \mathrm{~A} 5$ to sensitized unchallenged mice did not modify the number of the different cell types in BAL fluid (data not shown)

Effect of rmIL-10 on antigen-induced TNF- $\alpha$ generation in the $B A L$ fluid from sensitized mice. Antigen challenge by sensitized mice was also followed by a time-dependent generation of TNF- $\alpha$ in the BAL fluid, which peaked at $1 \mathrm{~h}$ and returned to basal levels thereafter (Fig. 7). BAL fluids collected 1, 3, or $24 \mathrm{~h}$ after the simultaneous administration of ovalbumin and rmIL-10 indicated a substantial reduction in the levels of TNF$\alpha$ (Fig. 7). Total inhibition at $1 \mathrm{~h}$ was achieved with $0.5 \mu \mathrm{g}$ rmIL-10, since $241.0 \pm 46.2$ and $69.0 \pm 4.8 \mathrm{pg} / \mathrm{ml}$ TNF- $\alpha$ were measured in the BAL fluid of antigen-challenged untreated or rmIL-10-treated mice, respectively, $(P<0.001, n=5-9)$.

Effect of anti-TNF- $\alpha$ antiserum on antigen-induced cellular infiltration in the BAL fluid from sensitized mice. The intranasal instillation of $50 \mu \mathrm{l}$ of a specific anti-TNF- $\alpha$ antiserum, concomitantly with ovalbumin, led to a significant reduction in both BAL neutrophils and eosinophils at 6 and $24 \mathrm{~h}$, respectively. Under the same conditions, control serum was ineffective (Table II).

\section{Discussion}

In the present study we show that IL-10, a Th2-derived cytokine (11), down-regulates antigen-induced airway inflammation in sensitized mice, since its local administration prevents neutrophil and eosinophil accumulation in the BAL fluid observed 6 and $24 \mathrm{~h}$ after the challenge, respectively. This effect is attributable to the biological activity of the cytokine, since inhibition by IL-10 of antigen-induced airway inflammation is suppressed when the sensitized mice are treated with a specific anti-IL-10 $\mathrm{mAb}$. It is noteworthy that in vivo neutralization of IL-10 further enhances the ovalbumin-induced cellular recruitment in the BAL fluid, suggesting that endogenously released IL-10 may be involved in the regulation of leukocyte homing to the airways. Systemic generation of IL-10 after intraperitoneal injection of anti-CD3 $\mathrm{mAb}$ or LPS to Balb/c mice has been reported by Durez et al. (22). Since both stimuli were effective in eliciting IL-10 release, it was suggested that IL-10 production can be achieved by stimulating different cell types. Thus, $\mathrm{CD}^{+}{ }^{+} \mathrm{T}$ cells are the major source of this cytokine upon CD3 stimulation (23), whereas macrophages and B cells are likely to be involved in LPS-induced $\mathrm{IL}-10$ release (13). These observations raise
A

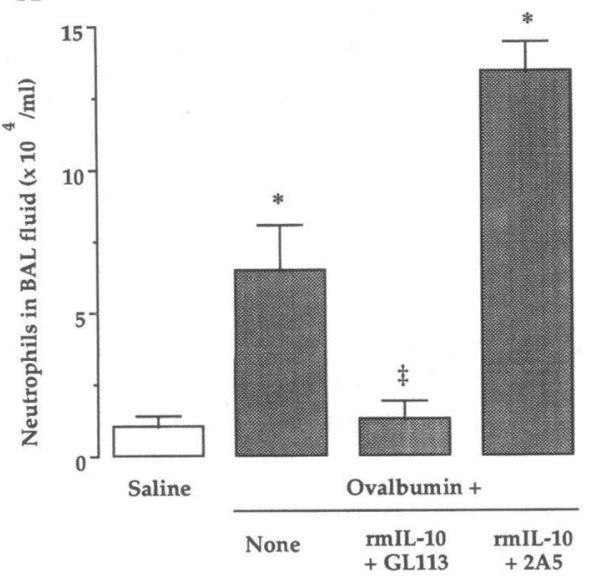

B

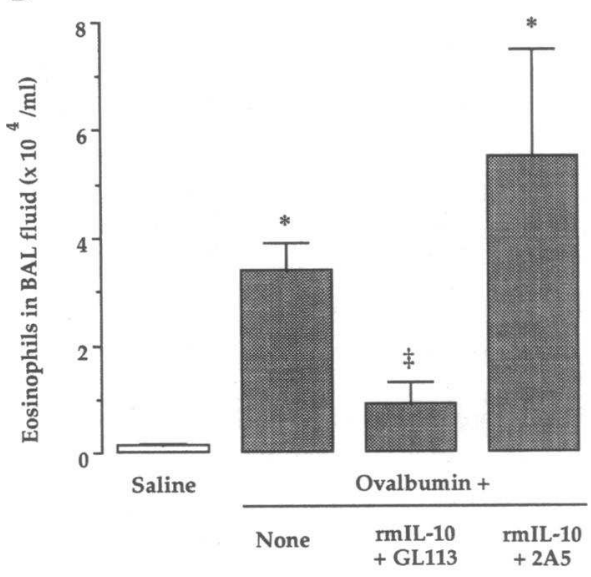

Figure 6. Effect of anti-IL-10 $\mathrm{mAb}$ on the inhibition by rmIL10 of antigen-induced cellular accumulation in the BAL fluid from sensitized mice. Mice were challenged by intranasal route either with saline, or with $10 \mu \mathrm{g}$ ovalbumin alone or concurrently administered with $0.1 \mu \mathrm{g}$ rmIL-10. Antigen-challenged animals were treated intravenously with $1 \mathrm{mg}$ / mouse of a specific anti-IL-10 $\mathrm{mAb}, 2 \mathrm{~A} 5$, of with its matched isotype, GL113, $1 \mathrm{~h}$ before ovalbumin administration. Neutrophil $(A)$ and eosinophil $(B)$ infiltration into the BAL fluid were evaluated 6 or $24 \mathrm{~h}$ after antigen challenge, respectively. Results are expressed as means $\pm S E M$ of five to six experiments for each group. ${ }^{*} P<0.05$ and ${ }^{\ddagger} P<0.05$, as compared to saline- or ovalbuminchallenged untreated mice, respectively. 


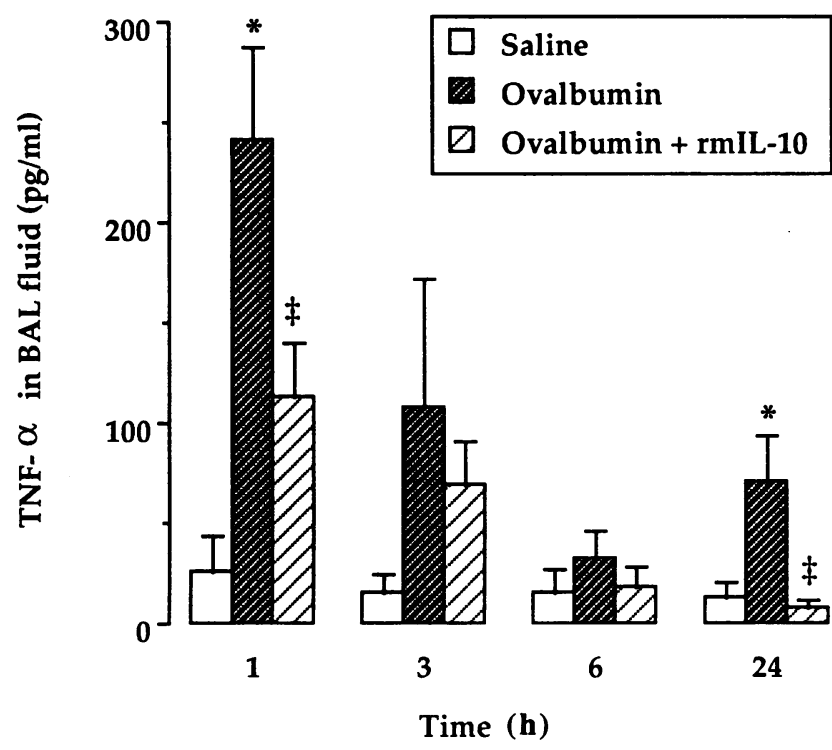

Figure 7. Inhibition by rmIL-10 of antigen-induced TNF- $\alpha$ generation in the BAL fluid from sensitized mice. Sensitized Balb/c mice were challenged with intranasal saline ( $\square$ ), or with $10 \mu \mathrm{g}$ ovalbumin, administered either alone $(\square)$ or with $0.1(\mathscr{E}) \mu \mathrm{g}$ rmIL-10 and they were killed at various time intervals after the challenge. The levels of TNF- $\alpha$ in the BAL fluid were evaluated by a double sandwich-specific ELISA. Results are expressed as means \pm SEM of five to nine experiments for each group. ${ }^{*} P<0.05$ and ${ }^{\ddagger} P<0.05$, as compared to saline- or ovalbuminchallenged untreated mice, respectively.

the question of the sources of IL-10 in ovalbumin-challenged mouse lung. Indeed, besides $\mathrm{CD} 4^{+} \mathrm{T}$ lymphocytes, which are present in increased numbers in the bronchial tissue of sensitized mice $24 \mathrm{~h}$ after antigen challenge (reference 9 and our unpublished results ), alveolar macrophages may also respond to antigen stimulation with IL-10 generation. Accordingly, Hamid et al. (24) described recently increased mRNA for IL-10 in BAL cells from asthmatics. In situ hybridization coupled with immunohistochemistry, revealed that IL-10 secreting cells were mostly $\mathrm{T}$ lymphocytes and macrophages (24).

Contrary to the inhibition of allergic airway inflammation observed when rmIL-10 was given by intranasal route, its subcutaneous injection did not modify antigen-induced cellular accumulation in the BAL fluid (data not shown). These results suggest that the target(s) for IL-10 are located in the airways and that the amounts of rmIL-10 reaching the bronchial compartment after its systemic administration are probably not sufficient to display an effect. Among the various bronchopulmonary targets for IL-10, the macrophage is a widely described cell type sensitive to this cytokine (13). Indeed, incubation of human or murine macrophages in the presence of IL-10 results in a marked down-regulation of their reactivity, particularly in terms of cytokine production and mediator release (25-27). On the other hand, IL-10 was first identified as a cytokine acting on Th1 clones and capable of inhibiting their IFN- $\gamma$ production $(11,12)$. However, protection by IL-10 of antigen-induced airway inflammation presently described seems unrelated to a blockade of IFN- $\gamma$ generation from lung T cells. Indeed, systemic (28) or bronchopulmonary (29) administration of IFN$\gamma$ to mice sensitized and challenged under conditions similar to those used in this study, prevents allergic eosinophil infiltration
Table II. Effect of the Anti-TNF- $\alpha$ Antiserum, or Its Control Preimmune Serum, on Antigen-induced Cellular Accumulation in the BAL Fluid from Sensitized Mice

\begin{tabular}{llll}
\hline $\begin{array}{c}\text { Challenge } \\
\text { intranasal }\end{array}$ & \multicolumn{1}{c}{$\begin{array}{c}\text { Treatment } \\
\text { intranasal }\end{array}$} & $\begin{array}{c}\text { Neutrophils at } 6 \mathrm{~h} \\
\left(10^{4} / \mathrm{ml} \mathrm{BAL} \text { fluid }\right)\end{array}$ & $\begin{array}{c}\text { Eosinophils at } 24 \mathrm{~h} \\
\left(10^{4} / \mathrm{ml} \mathrm{BAL} \mathrm{fluid}\right)\end{array}$ \\
\hline Saline & None & $1.31 \pm 0.35$ & $0.04 \pm 0.03$ \\
Ovalbumin & None & $4.54 \pm 1.10^{*}$ & $3.70 \pm 1.09 *$ \\
Ovalbumin & Preimmune serum & $6.32 \pm 2.11^{*}$ & $4.93 \pm 1.50^{*}$ \\
Ovalbumin & anti-TNF- $\alpha$ antiserum & $0.76 \pm 0.27^{* \ddagger}$ & $0.46 \pm 0.19^{*} \neq$
\end{tabular}

Cellular distribution in the BAL fluid from sensitized mice challenged with intranasal saline or ovalbumin and treated concomitantly, via the intranasal route, with $50 \mu \mathrm{l} /$ mouse of a sheep anti-murine TNF- $\alpha$ antiserum or with its control preimmune serum. Results represent the number of neutrophils or eosinophils $\times 10^{4} \mathrm{ml}$ BAL fluid. Data are expressed as means \pm SEM of four to nine experiments. ${ }^{*} P<0.05$, as compared to saline-challenged untreated mice. ${ }^{\ddagger} P<0.05$, as compared to ovalbumin-challenged untreated mice. ${ }^{8} P<0.05$, as compared to ovalbumin-challenged control serum-treated mice.

into the tracheal tissue. This effect is compatible with the inhibition by IFN- $\gamma$ of Th 2 clone proliferation (30), and subsequent production of cytokines, such as IL-5, which is selectively involved in eosinophil mobilization (5-7).

The data presented herein show that rmIL-10 is equally effective in preventing both neutrophil and eosinophil infiltration into the airways of antigen-challenged mice. This suggests that IL-10 may regulate the expression and/or the release of factors involved in the migration of these two cell types to the lung. Interestingly enough, when administered $1 \mathrm{~h}$ after the challenge, rmIL-10 failed to protect sensitized mice from antigen-induced cellular accumulation in the BAL fluid. This observation led us to hypothesize that IL-10 may modulate the local release of preformed and thus rapidly released cytokines, which are potentially involved in allergic leukocyte recruitment.

Several lines of evidence designate TNF- $\alpha$ as a cytokine generated by numerous cell types during inflammatory reactions and shock states (reviewed in reference 31 ). The participation of TNF- $\alpha$ in allergic reactions is linked to different observations, including its release by mast cells, basophils, and alveolar macrophages upon IgE-dependent mechanisms (32-35). High levels of TNF- $\alpha$ have been shown in monocytes and epithelial cells from asthmatics (36) and BAL fluid from antigen-challenged guinea pigs (37). Finally, treatment of sensitized guinea pigs with an IL-1 receptor antagonist prevents antigen-induced eosinophil accumulation and TNF- $\alpha$ generation in the BAL fluid (37), indicating that TNF- $\alpha$ may modulate allergic airway inflammation. We thus investigated whether antigen challenge induced the release of this cytokine in the BAL fluid of sensitized mice and verified the potential modulatory activity of IL10 in this process. The intranasal administration of ovalbumin was followed by a marked rise in the levels of TNF- $\alpha$ in the BAL fluid, which reached a peak at $1 \mathrm{~h}$ to resolve between 3 and $6 \mathrm{~h}$ after the challenge. rmIL-10 dose-dependently inhibited this release, a result extending previous observations showing reduction by IL-10 of LPS-induced in vivo TNF- $\alpha$ generation $(16,17)$. Thus, the observation that TNF- $\alpha$ released upon antigenic stimulation is also susceptible of inhibition by IL-10 may have important consequences for the subsequent invasion of the bronchial wall by inflammatory cells. Accordingly, failure by 
IL-10 to modify antigen-induced cellular infiltration when administered $1 \mathrm{~h}$ after the challenge, i.e., the time of the peak release of TNF- $\alpha$ in the BAL fluid, support the hypothesis that blockade of local TNF- $\alpha$ generation and inhibition of leukocyte recruitment are related phenomena. In confirmation, we demonstrate that the local administration of an antiserum to TNF- $\alpha$ markedly reduced antigen-induced neutrophil and eosinophil accumulation in the BAL fluid. These results extend those from previous studies showing the participation of TNF- $\alpha$ in leukocyte infiltration associated with IgE-dependent cutaneous inflammation in sensitized mice (38).

As whole rat lung tissue passively sensitized with monoclonal IgE antibody was shown to produce TNF- $\alpha$ after antigen stimulation (39), the presence of bronchopulmonary source( $s$ ) for this cytokine, particularly macrophages and mast cells, has been suggested. Indeed, macrophages, which are directly involved in allergic responses through the presence of Fc $\epsilon$ RII receptors at their surface (40), produce and express TNF- $\alpha$ upon IgE-dependent stimulation (35). Similarly, IgE-mediated activation of mast cells triggers the release of TNF- $\alpha$, which, in this cell type, is stored in the cytoplasmic granules (41) and rapidly secreted upon stimulation. However, while macrophage deactivation by IL-10 is well documented $(13,25-27)$, modulation by IL-10 of IgE-dependent responses on mast cells, including TNF- $\alpha$ generation, has not been described yet.

Once released in the airways, TNF- $\alpha$ may display a broad spectrum of biological activities, including activation and chemotaxis of eosinophils $(42,43)$ and neutrophils $(44,45)$. Interestingly enough, TNF- $\alpha$ directly stimulates the expression of adhesion molecules on cultured endothelial cells $(46,47)$, and, in vivo, in the baboon's skin (48). These molecules, which include intercellular adhesion molecule-1 (ICAM-1) and vascular cell adhesion molecule-1 (VCAM-1), are responsible for the adhesion of leukocytes to the endothelium. This is followed by their transendothelial migration and subsequent infiltration into the inflamed tissues. Accordingly, treatment of sensitized Balb/c mice with anti-ICAM-1 or anti-VCAM-1 mAbs, suppressed antigen-induced cellular recruitment into the tracheal tissue (49). Whether adhesion molecule expression in the allergic lung is also directly or indirectly regulated by IL-10 is an area for a further investigation.

In conclusion, our findings demonstrate that, when compared to other Th2-derived cytokines, such as IL-4 and IL5 , IL-10 is unique in down-regulating antigen-induced airway inflammation in the mouse. This evidence suggests that IL-10 production during allergic responses, may represent an important regulatory mechanism in the control of tissue inflammation in which leukocyte infiltration is a prominent feature. Consequently, therapeutic agents aimed to positively regulate IL-10 generation and/or its receptor interaction may have a promising future as inhibitors of allergic bronchopulmonary inflammation.

\section{References}

1. Holgate, S. T. 1993. Asthma: past, present and future. Eur. Respir. J. 6:1507-1520.

2. Hamid, Q., M. Azzawi, S. Ying, R. Moqbel, A. J. Wardlaw, C. J. Corrigan, B. Bradley, S. R. Durham, J. V. Collins, P. K. Jeffery, et al. 1991. Expression of mRNA for interleukin-5 in mucosal bronchial biopsies from asthma. J. Clin. Invest. 87:1541-1546.

3. Kay, A. B., S. Ying, V. Varney, M. Gaga, S. R. Durham, R. Moqbel, A. J. Wardlaw, and Q. Hamid. 1991. Messenger RNA expression of the cytokine gene cluster, interleukin 3 (IL-3), IL-4, IL-5, and granulocyte/macrophage colony- stimulating factor, in allergen-induced late-phase cutaneous reactions in atopic subjects. J. Exp. Med. 173:775-778.

4. Robinson, D. S., Q. Hamid, S. Ying, A. Tsicopoulos, J. Barkans, A. M Bentley, C. Corrigan, S. R. Durham, and A. B. Kay. 1992. Predominant Th2-like bronchoalveolar T-lymphocyte population in atopic asthma. N. Engl. J. Med. 326:298-304.

5. Clutterbuck, E. J., E. M. Hirst, and C. J. Sanderson. 1989. Human interleukin-5 (IL-5) regulates the production of eosinophils in human bone marrow cultures: comparison and interaction with IL-1, IL-3, IL-6, and GM-CSF. Blood. 73:1504-1512.

6. Sanderson, C. J. 1992. Interleukin-5, eosinophils, and disease. Blood. 79:3101-3109.

7. Sanderson, C. J., D. J. Warren, and M. Strath. 1985. Identification of a lymphokine that stimulates eosinophil differentiation in vitro. Its relationship to interleukin-3, and functional properties of eosinophils produced in cultures. $J$. Exp. Med. 162:60-74.

8. Pene, J., F. Rousset, F. Brière, I. Chrétien, J. Y. Bonnefoy, H. Spits, T Yokota, N. Arai, K.-I. Arai, J. Banchereau, and J. E. de Vries. 1988. IgE production by human B cells is induced by IL- 4 and suppressed by interferons $\gamma$ and $\alpha$ prostaglandin E2. Proc. Natl. Acad. Sci. USA. 85:6880-6884.

9. Nakajima, H., I. Iwamoto, S. Tomoe, R. Matsumura, H. Tomioka, K. Takatsu, and S. Yoshida. 1992. CD4 ${ }^{+}$T-lymphocytes and interleukin-5 mediate antigen-induced eosinophil infiltration into the mouse trachea. Am. Rev. Respir. Dis. 146:374-377.

10. Lukacs, W. N., R. M. Strieter, S. W. Chensue, and S. L. Kunkel. 1994. Interleukin-4-dependent pulmonary eosinophil infiltration in a murine model of asthma. Am. J. Respir. Cell. Mol. Biol. 10:526-532.

11. Fiorentino, D. F., M. W. Bond, and T. R. Mosmann. 1989. Two types of mouse T helper cell: IV. Th2 clones secrete a factor that inhibits cytokine production by Th1 clones. J. Exp. Med. 170:2081-2095.

12. Hsu, D.-H., K. W. Moore, and H. Spits. 1992. Differential effects of interleukin- 4 and -10 on interleukin-2-induced interferon- $\gamma$ synthesis and lymphokine-activated killer activity. Int. Immunol. 4:563-569.

13. Moore, K. W., A. O'Garra, R. de Waal Malefyt, P. Vieira, and T. R. Mosmann. 1993. Interleukin-10. Annu. Rev. Immunol. 11:165-190.

14. Cassatella, M. A., L. Meda, S. Bonora, M. Ceska, and G. Constantin. 1993. Interleukin-10 (IL-10) inhibits the release of proinflammatory cytokines from human polymorphonuclear leukocytes. Evidence for an autocrine role of tumor necrosis factor and IL- $1 \beta$ in mediating the production of IL- 8 triggered by lipopolysaccharide. J. Exp. Med. 178:2207-2211.

15. Kasama, T., R. M. Strieter, N. W. Lukacs, M. D. Burdick, and S. L. Kunkel. 1994. Regulation of neutrophil-derived chemokine expression by IL-10. J. Immunol. 152:3559-3569.

16. Takanashi, S., R. Nonaka, Z. Xing, P. O’Byrne, J. Dolovich, and M. Jordana. 1994. Interleukin 10 inhibits lipopolysaccharide-induced survival and cytokine production by human peripheral blood eosinophils. J. Exp. Med. 180:711-715.

17. Howard, M., T. Muchamuel, S. Andrade, and S. Menon. 1993. Interleukin 10 protects mice from lethal endotoxemia. J. Exp. Med. 177:1205-1208.

18. Gérard, C., C. Bruyns, A. Marchant, D. Abramowicz, P. Vandenabeele, A. Delvaux, W. Fiers, M. Goldman, and T. Velu. 1993. Interleukin 10 reduces the release of tumor necrosis factor and prevents lethality in experimental endotoxemia. J. Exp. Med. 177:547-550.

19. Zuany-Amorim, C., B. B. Vargaftig, J. Maclouf, and M. Pretolani. 1994 Strain-dependency of leukotriene $\mathrm{C}_{4}$ generation from isolated lungs of immunised mice. Br. J. Pharmacol. 112:1230-1236.

20. Lapa e Silva, J. R., C. M. Bachelet, M. Pretolani, D. Baker, R. J. Scheper, and B. B. Vargaftig. 1993. Immunopathologic alterations in the bronchi of immunized guinea-pigs. Am. J. Respir. Cell Mol. Biol. 9:44-53.

21. Karkar, A. K., F. W. K. Tam, A. E. I. Proudfoot, A. Meager, and A. J. Rees 1993. Modulation of antibody-mediated glomerular injury in vivo by interleukin-6. Kidney Int. 44:967-973.

22. Durez, P., D. Abramowicz, C. Gérard, M. Van Mechelen, Z. Amraoui, C. Dubois, O. Leo, T. Velu, and M. Goldman. 1993. In vivo induction of interleukin 10 by anti-CD3 monoclonal antibody or bacterial lipopolysaccharide: differential modulation by cyclosporin A. J. Exp. Med. 177:551-555.

23. Svetic, A., F. D. Finkelman, Y. C. Jian, C. W. Dieffenbach, D. E. Scott, K. F. McCarthy, A. D. Steinberg, and W. C. Gause. 1991. Cytokine gene expression after in vivo primary immunization with goat antibody to mouse IgD antibody. J. Immunol. 147:2391-2397.

24. Hamid, Q., S. Ying, D. Robinson, S. R. Durham, and A. B. Kay. 1994 IL-10 mRNA is increased in asthma and co-localized with CD3 and CD68. Am J. Respir. Crit. Care Med. 149:958a. (Abstr.)

25. Fiorentino, D. F., A. Zlotnik, T. R. Mosmann, M. Howard, and A. O'Garra 1991. IL-10 inhibits cytokine production by activated macrophages. J. Immunol. 147:3815-3822.

26. de Waal Malefyt, R., J. Abrams, B. Bennett, C. G. Figdor, and J. E. de Vries. 1991. Interleukin 10 (IL-10) inhibits cytokine synthesis by human monocytes: an autoregulatory role of IL-10 produced by monocytes. J. Exp. Med. 174:1209-1220. 
27. Bogdan, C., Y. Vodovotz, and C. Nathan. 1991. Macrophage deactivation by interleukin 10. J. Exp. Med. 174:1549-1555.

28. Iwamoto, I., H. Nakajima, H. Endo, and S. Yoshida. 1993. Interferon $\gamma$ regulates antigen-induced eosinophil recruitment into the mouse airways by inhibiting the infiltration of CD4 ${ }^{+}$T-cells. J. Exp. Med. 177:573-576.

29. Nakajima, H., I. Iwamoto, and S. Yoshida. 1993. Aerosolized recombinant interferon-gamma prevents antigen-induced eosinophil recruitment in mouse trachea. Am. Rev. Respir. Dis. 148:1102-1104.

30. Gajewski, T. F., and F. W. Fitch. 1988. Anti-proliferative effect of IFN$\gamma$ in immune regulation. I. IFN- $\gamma$ inhibits the proliferation of Th2 but not Th1 murine helper T lymphocyte clones. J. Immunol. 140:4245-4252.

31. Tracey, K. J., and A. Cerami. 1993. Tumor necrosis factor, other cytokines and disease. Annu. Rev. Cell Biol. 9:317-343.

32. Burd, P. R., H. W. Rogers, J. R. Gordon, C. A. Martin, S. Jayaraman, S. D. Wilson, A. M. Dvorak, S. J. Galli, and M. E. Dorf. 1989. Interleukin 3dependent and -independent mast cells stimulated with IgE and antigen express multiple cytokines. J. Exp. Med. 170:245-257.

33. Gordon, J. R., and S. J. Galli. 1990. Mast cells as a source of both preformed and immunologically inducible TNF- $\alpha /$ cachectin. Nature (Lond.). 346:274-276.

34. Ohno, I., K. Yamaguchi, and T. Takashima. 1990. Gene expression and production of tumor necrosis factor by a rat basophilic cell line (RBL-2H3) with IgE receptor triggering. Immunology. 70:88-93.

35. Gosset, P., M. Tsicopoulos, B. Wallaert, C. Vannimenus, M. Joseph, A.-B. Tonnel, and A. Capron. 1991. Increased secretion of tumor necrosis factor $\alpha$ and interleukin- 6 from alveolar macrophages consecutive to the development of the late asthmatic reaction. J. Allergy Clin. Immunol. 88:561-571.

36. Mattoli, S., V. L. Mattoso, M. Soloperto, L. Allegra, and A. Fasoli. 1991. Cellular and biochemical characteristics of bronchoalveolar lavage fluid in symptomatic nonallergic asthma. J. Allergy Clin. Immunol. 87:794-802.

37. Watson, M. L., D. Smith, A. D. Bourne, R. C. Thompson, and J. Westwick. 1993. Cytokines contribute to airway dysfunction in antigen-challenged guineapigs: inhibition of airway hyperreactivity, pulmonary eosinophil accumulation, and tumor necrosis factor generation by pretreatment with an interleukin-1 receptor antagonist. Am. J. Respir. Cell Mol. Biol. 8:365-369.

38. Wershil, B. K., Z.-S. Wang, J. R. Gordon, and S. J. Galli. 1991. Recruitment of neutrophils during IgE-dependent cutaneous late phase reactions in the mouse is mast cell dependent: partial inhibition of the reaction with antiserum against tumor necrosis factor-alpha. J. Clin. Invest. 87:446-453.
39. Ohno, I., Y. Ohkawara, K. Yamauchi, Y. Tanno, and T. Takishima. 1990. Production of tumor necrosis factor with IgE receptor triggering from sensitized lung tissue. Am. J. Respir. Cell Mol. Biol. 3:285-289.

40. Capron, A., J. P. Dessaint, M. Capron, M. Joseph, J. C. Ameisen, and A. B. Tonnel. 1986. From parasites to allergy: a second receptor for IgE. Immunol. Today. 7:15-18.

41. Bakouche, O., Y. Ichinose, R. Heicappell, I. J. Fidler, and L. B. Lachman. 1988. Plasma membrane-associated tumor necrosis factor: a non-integral membrane protein possibly bound to its own receptor. J. Immunol. 140:1142-1147.

42. Lamas, A. M., C. M. Mulroney, and R. P. Schleimer. 1988. Studies on the adhesive interactions between purified human eosinophils and cultured vascular endothelial cells. J. Immunol. 140:1500-1505.

43. Takafuji, S., S. C. Bischoff, A. L. De Weck, and C. A. Dahinden. Opposing effects of tumor necrosis factor-alpha and nerve growth factor upon leukotriene $\mathrm{C}_{4}$ production by human eosinophils triggered with $\mathrm{N}$-formylmethionyl-leucylphenylalanine. Eur. J. Immunol. 22:969-974.

44. Ming, W. J., L. Bersani, and A. Mantovani. 1987. Tumor necrosis factor is chemotactic for monocytes and polymorphonuclear leukocytes. J. Immunol. 138:1469-1474.

45. Klebanoff, S. J., M. A. Vadas, J. M. Harlan, L. H. Sparks, J. R. Gamble, J. M. Agosti, and A. M. Waltersdorph. 1986. Stimulation of neutrophils by tumor necrosis factor. J. Immunol. 136:4220-4225.

46. Pober, J. S., L. A. Lapierre, A. H. Stolpen, T. A. Brock, T. A. Springer, W. Fiers, M. P. Bevilacqua, D. L. Mendrick, and M. A. Ginbrone, Jr. 1987. Activation of cultured human endothelial cells by recombinant lymphotoxin: comparison with tumor necrosis factor and interleukin-1 species. J. Immunol. 138:3319-3324.

47. Thornhill, M. H., and D. O. Haskard. 1990. IL-4 regulates endothelial cell activation by IL-1, tumor necrosis factor, or IFN- $\gamma$. J. Immunol. 145:865-872.

48. Briscoe, D. M., R. S. Cotran, and J. S. Pober. 1992. Effects of tumor necrosis factor, lipopolysaccharide, and IL-4 on the expression of vascular cell adhesion molecule-1 in vivo. Correlation with $\mathrm{CD}^{+} \mathrm{T}$ cell infiltration. J. Immunol. 149:2954-2960.

49. Nakajima, H., H. Sano, T. Nishimura, S. Yoshida, and I. Iwamoto. 1994. Role of vascular cell adhesion molecule 1 /very late activation antigen 4 and intercellular adhesion molecule 1/lymphocyte function-associated antigen 1 interactions in antigen-induced eosinophil and $\mathrm{T}$ cell recruitment into the tissue. $J$. Exp. Med. 179:1145-1154. 